\title{
THUTHUKA STUDENTS’ PERCEPTIONS OF FACTORS INFLUENCING SUCCESS
}

\author{
Eloise de Jager" \\ University of Stellenbosch \\ edejager@sun.ac.za.
}

Received: December 2012

Accepted: November 2013

\begin{abstract}
South Africa has a shortage of black (African and coloured) chartered accountants. The Thuthuka Project, initiated by the South African Institute for Chartered Accountants (SAICA), aims to increase the number of black accounting students. The Thuthuka Project includes funding, as well as a comprehensive support programme, for black students to study BCom Accounting (or equivalent) at a SAICA-accredited university. This article reports on research into the factors that promote and hinder the academic success of Thuthuka students. The findings of this study might help other students to achieve success and may assist in the transformation of the chartered accountancy profession. A questionnaire was used to gather data on the perceived success factors of Thuthuka students (from all the SAICA-accredited universities in South Africa). It was found that Thuthuka students believed that support was the main factor contributing to their success, followed by individual commitment.
\end{abstract}

Keywords

Thuthuka, Student perceptions, Success factors, Transformation, Black students, Chartered accountant, Support

Mrs $\varepsilon$ de Jager is a lecturer in the School of Accountancy at Stellenbosch University, South Africa. 


\section{INTRODUCTION}

The South African Institute of Chartered Accountants (SAICA) views effective transformation and growth of the chartered accountancy profession as crucial and has made a strategic commitment to develop and empower previously disadvantaged South Africans (SAICA, 201la). South Africa remains in need of black chartered accountants (CAs) (Sadler \& Erasmus, 2005). However, statistics released by SAICA in 2009 revealed a dramatic improvement in the accounting profession's gender and racial demo graphics. Chantyl Mulder, SAICA's senior executive for transformation and growth, announced that the efforts of SAICA and the profession to increase the number of black chartered accountants are starting to bear fruit (SAICA, 2009). Despite the change in racial demographics, in December 2011 only 3059 of the 33167 CAs in South Africa were black (African and coloured) (SAICA, 2011b). Odendaal and Joubert (2011) claim that the shortage of qualified accountants is one of the pressing issues facing the accounting profession, and they point out that the black segments of the South African population are especially underrepresented.

Student success rates are a great concern in South African higher education institutions. Even though the pass rates of black students studying towards becoming a CA have improved, they are still unacceptably low (Sehoole, 2010; Sadler \& Erasmus, 2005). These low pass rates could be one of the reasons contributing to the shortage of black CAs (Sehoole, 2010; Sadler \& Erasmus, 2005). Only about one-third of a sample of students in the public higher education system (selected by the Parliamentary Monitoring Group) completed their qualification in the minimum prescribed time. In the portion of the sample that took longer than the minimum prescribed time, $75 \%$ were black students (Malele, 2011). The academic success rates for black and white students are very different: attrition rates for black students are much higher than those of white students (Stephen, Welman \& Jordaan, 2004). According to the project director of the Thuthuka Bursary Fund, Mr Selebi, the pass rate of black students requires a $70 \%$ increase to avoid a negative impact on the employment equity of the accounting profession and to prevent a supply shortage of black CAs (Selebi, 2007).

Since the 1980s various initiatives have been launched by a number of higher education institutions and professional institutions to address the shortage of black CAs (Weil \& Wegner, 1997). SAICA's executive president, Ignatius Sehoole, said in 2003 that the long-term strategy for SAICA is to boost the nation's black CAs (Sadler \& Erasmus, 2003). SAICA started several initiatives to increase the success rates of black students (Sadler \& Erasmus, 2005), the largest project being Thuthuka. According to SAICA (2012a:1), 'Thuthuka is a Zulu verb, meaning "to develop", indicating the action-based perspective with which transformation is being driven'. This project was initiated to change the demographics of the chartered accountancy profession's membership to reflect the race and gender demographics of the population of South Africa (SMVPS, 2012).

In the following section the background and the aim of the study are discussed, and this is followed by the literature review. This sets the stage for the methodology. After the presentation and discussion of the results, the conclusions and recommendations are set out in the final section. 


\section{BACKGROUND AND AIM OF STUDY}

In a study by Sadler and Erasmus (2003), black trainees identified a lack of funding and bursaries as reasons for the small number of black CAs in the country. In 2002 SAICA initiated the Thuthuka Project, which consists of the Thuthuka Upliftment Project and the Thuthuka Bursary Fund. The Thuthuka Project is aimed at increasing the success of black students by increasing the admission numbers and improving their pass rates (Rudman, 2011).

The Thuthuka Upliftment Project consists of a number of education- and community-related programmes on secondary (school) level, tertiary level and post-education level (Selebi, 2007). The Thuthuka Bursary Fund is an initiative focused at the tertiary level. Its purpose is to place between 250 and 300 full-bursary African and coloured students at selected SAICA-accredited universities on special undergraduate $B C o m$ Accounting (or equivalent) education programmes annually (to increase the number of registered African and coloured university students) (SAICA, 2012b). The Thuthuka Bursary Fund offers a bursary for three years for full-time undergraduate students, as well as a bursary for one year for postgraduate students (Selebi, 2007) who are studying towards becoming CAs.

Every year a number of students are admitted to the Thuthuka programme at Thuthukaaccredited universities throughout South Africa. These Thuthuka students are registered for the $\mathrm{BCom}$ Accounting (or equivalent) or BCom Accounting honours (or CTA equivalent) degree courses. The admission criteria for the courses require that students must have achieved a minimum percentage for mathematics at school. The course is presented in either Afrikaans or English, depending on the language policy of the particular university. It is expected that at most universities the language of tuition is not the Thuthuka students' first language.

Possible ways of assisting black students is by introducing academic support programmes and establishing formal mentorship programmes (Sadler \& Erasmus, 2003). Various academic and personal support programmes are available to the Thuthuka students at the universities. These programmes vary from university to university but overall they include the following:

- Academic trainees: Academic trainees help students one on one.

- Residential accommodation: All students stay in accommodation supplied through the funding of SAICA.

- Life skills workshops: Workshops are presented to help the students develop those skills that are needed in the workplace.

- Mentoring system: Every Thuthuka student is allocated either a senior Thuthuka student or a lecturer or a study group to act as his/her mentor.

- Support classes: Tutorials and extra lectures additional to the normal classes are provided.

- Support from the psychological centre: The centre provides student support services.

- Thuthuka coordinator: The Thuthuka coordinator is always available for support.

Over the years, the pass rates of the Thuthuka students were impressive at university level and even more impressive in the first qualifying examinations (SMVPS, 2012). The pass rate for Thuthuka students (on both university level and in the qualifying examinations) are above those of their peers (including other black students). The throughput pass rate for the undergraduate 
(first-, second-and third-year) Thuthuka students (an average of 79\%) exceeds the national average of African students (22\%) studying towards a CA qualification (SAICA, 201lc). Since 2007, when the first group of Thuthuka students wrote the professional qualifying examination, the pass rates of the Thuthuka students was well above the national and African candidates' throughput rate (SAICA, 2011d). However, although the throughput rates of the black students has increased since the inception of the Thuthuka Project, the percentage is still below $50 \%$ (Selebi, 2007).

Thuthuka students differ from other accounting students, as more support structures are offered to them and they are encouraged to utilise the resources available to them. Thuthuka students are made aware of the importance of developing skills required by the competency framework of SAICA (SAICA, 2009). This includes professional skills, as well as skills related to the required work ethic and personal attributes. Participation in the support programmes could enhance these skills. Other accounting students are not necessarily exposed to the available support programmes in the same structured manner as Thuthuka students. It was deemed important to investigate the factors that lead to the success of Thuthuka students, as the pass rate for Thuthuka students was above that of their peers (including other black students), as mentioned earlier. By achieving academic success, Thuthuka students can be an example for other aspiring black CAs (Sadler, 2003).

Given the difference in pass rates and exposure to support programmes, it can be expected that the success factors of Thuthuka students may differ from those of other accounting students. The aim of the study was to investigate Thuthuka students' perceptions of factors that influence their success in the BCom Accounting (or equivalent) degree at all the SAICA-accredited South African universities that offer the Thuthuka Bursary programme. The information may provide valuable information to other black students, lecturers and SAICA.

\section{LITERATURE REVIEW}

Gracia and Jenkins (2002) contend that academic success is important to students, as academic failure could give rise to financial and emotional burdens. According to Fraser and Killen (2003), academic success occurs when students are able to meet the assessment requirements of the programme for which they are registered. Greater success is achieved if these requirements can be met in the minimum prescribed time than if subjects have to be repeated.

Students' perceptions will improve accounting lecturers' understanding of the factors that affect students' academic success (Byrne \& Flood, 2005). Asking students directly seems to be the most appropriate approach to determine their experiences (Bowman \& Seifert, 2011). It can be expected that students of different profiles - especially race - have different perceptions. This fact is important, especially in the South African context (Carpenter, Friar \& Lipe, 1993).

Previous research has shown that there are various factors that can influence student success. Some of the factors that may play a role in student success are discussed below.

\subsection{Support}

Academic, financial and personal support are factors that are mentioned regularly in the literature. Academic support structures offered by higher education institutions have a great impact on student success (Kleeman, 1994). The use of mentors provides a good learning 
opportunity for students. Sadler and Erasmus (2005) found that black accounting students want SAICA to introduce academic support programmes, which they believe will help them pass the examinations. Other examples of support structures that are consistent with the structures that are in place for Thuthuka students are:

- Tutorial classes (Isaacs, 2007);

- Academic trainees or peer mentors, i.e. students who have the same or slightly higher ability (Monroe, 2002);

- A coordinator of the programme (e.g. Thuthuka coordinator) who fulfils certain roles, inter alia mentor, psychiatrist and representative of formal authority (Naudé, 2002).

Financial support is an important factor. It was found that one of the reasons why so few black students chose to become CAs was the lack of funding and bursaries (Sadler \& Erasmus, 2003, 2005). Studies have also found that personal and social support from either family members or another person affects academic performance (Gerdes \& Mallinckrodt, 1994). Pritchard and Wilson (2003) found that emotional and social factors (e.g. stress) are related to academic success or failure. Non-financial personal problems (e.g. medical problems and family issues) were also found to have a direct influence on retention rates (Bennett, 2003).

\subsection{Class attendance}

Class attendance is often cited in the literature as a factor influencing students' success. Gracia and Jenkins (2002) found that poor class attendance was one of the reasons for student academic failure. The results of a study by Steenkamp, Baard and Frick (2009) indicated that students who attended more classes had a significantly greater chance of success.

\subsection{Individual commitment}

According to the literature, individual commitment was found to be an important influencer of academic success. In a study by Gracia and Jenkins (2002:98), 'I didn't do enough work,' was one of the reasons for academic failure given by a respondent. According to McInnis (2003), the amount of time and effort that students put into their studies is the most important factor for academic success. De Jager (2010) found that students perceived hard work as a factor that would help them to achieve academic success.

\subsection{Motivation}

In a study by Fraser and Killen (2005), self-discipline and self-motivation were found to be factors that contribute to success. Poor motivation was identified as a key variable for attrition among students (Ozga \& Sukhnandan, 1998). Harrell, Caldwell and Doty (1985) found a positive correlation between a student's motivation to strive for success and the student's academic performance.

\subsection{Time management}

Students perceive a lack of time as a limiting factor to their success (Steenkamp, Baard \& Frick, 2009). There is also a positive correlation between academic success and time management (Byrne, Flood \& Willis, 2002). 


\subsection{Other factors}

Interest in the course was found to be one of the most significant factors influencing student success in a study by Schmelzer, Schmelzer, Figler and Brozo in 1987 (Fraser \& Killen, 2005). 'I think I failed modules because I didn't like them,' was the feedback from one of the students in the study by Gracia and Jenkins (2002:98). Sometimes students' families expect them to follow a certain course or they receive a bursary to study in a certain field, but they do not enjoy the course. This could be especially true of Thuthuka students.

Language is a factor that can influence academic success. This could be caused by a general lack of language proficiency or studying in a language other than one's home language. In various studies (Sadler, 2003; Steenkamp, Baard \& Frick, 2009; Sadler \& Erasmus, 2003) it was found that the students perceived a lack of language proficiency to be a factor that hindered their success. Even studies abroad found language to be a factor that may influence student success. Weil and Wegner (1997) referred to an American study that found that language barriers can hold back a student from academic success. A study in Hong Kong (Wong \& Chia, 1996), where the population were studying in a language (English) other than their home language, found that English proficiency was related to the level of the students' performance in accounting. In South Africa, for most black students, English is not their first language, or even their second language (Memani, 1994, cited in Sadler, 2003). For most Thuthuka students the language of tuition is not their first language.

Studies have found that students with prior accounting and mathematics knowledge perform better in accounting at university (Mitchell, 1988; Tho, 1994). In a study by Gist, Goedde and Ward (1996), performance in mathematics at school was found to be the third main contributing factor to success among black students in accounting. Studies have also found that students who are not repeating a module (first-time students) are more successful (De Lange, Waldmann \& Wyatt, 1997; Du Plessis, Muller \& Prinsloo, 2007).

\section{METHODOLOGY}

A mixed method using a structured questionnaire including both open-ended and closed questions was used to investigate Thuthuka students' perceptions of the factors influencing their success in a BCom Accounting (or equivalent) course. The methodology employed in the research is discussed in the sections that follow $(4.1-4.3)$.

\subsection{The questionnaire and data analysis}

A questionnaire was developed based on the findings of the research discussed in the literature review, including the questionnaires used by Steenkamp et al. (2009). The questions were modified to address factors unique to Thuthuka students. The questionnaire consisted of three sections, and collected both quantitative and qualitative data. The first section consisted of general information regarding the students (gender, academic year and whether they were repeating subjects or not).

The second section contained both open-ended and closed-ended questions. The open-ended questions were designed to capture student perceptions of the factors that may influence their success. The comments of the students were analysed and categorised into high-level factors based on those identified during the literature review, i.e. support, individual commitment, 
motivation, class attendance and time management. Where other items (e.g. personal and academic problems) were mentioned often, each item was categorised in one separate category under 'other'. The number of times each factor was mentioned by the students was tallied and the factors were then ranked from those mentioned most to those mentioned least.

Other questions (open-ended and closed-ended) were included in the second section to gather more data about the factors influencing their success in general. Examples include what type of academic and personal support students utilised and reasons for non-class attendance, among other issues. These details, together with the description of the categorised factors from the open-ended questions, were used as qualitative data. The ranking of the categories constitutes quantitative data.

The third section consisted of a pre-established list of factors that may influence the success of Thuthuka students. Students were asked to indicate to what extent the items influenced their success, using a Likert scale of $1-4$, anchored by $1=$ no impact and $4=$ huge impact. These items were also categorised into the same high-level factors identified during the literature review. The results of section three provided additional quantitative data.

The results of section two and three were compared with each other to determine whether the open-ended results agreed with the ranking of the pre-established list of factors. This strengthened the results.

Since the focus was on the success factors of Thuthuka students it was important to define success for the purposes of this study. Success was defined (and explained in the questionnaire) as follows: first-year students achieved a progress mark of more than $50 \%$ for a particular subject and second-year, third-year and honours students passed a particular subject.

\subsection{The population}

There were 939 registered Thuthuka students at the SAICA-accredited Thuthuka Bursary Fund universities in 2011. Questionnaires were sent to the Thuthuka coordinators at each university, who distributed the questionnaires to their Thuthuka students. The coordinators explained the purpose of the research and ensured the confidentiality of the information. Responses were received from 468 students (a response rate of $50 \%$ ).

\subsection{Limitations}

Limitations to the study were that it focused predominantly on students' own perceptions, which might not have been a reflection of reality, and it did not investigate different schooling backgrounds, which could have had an impact on students' knowledge, skills and needs.

\section{RESULTS}

The results section starts with the respondents' profile. Next, the results of the open-ended and closed-ended questions are discussed under the headings 'factors promoting success' and 'factors preventing success'. Lastly, the ranking of the pre-established list of factors are presented. 


\subsection{General information}

The results are discussed according to the respondents' profile, including their gender, academic year and whether they were repeating subjects or not. The respondents' profiles are illustrated in

TABLE 1: Respondent profile

\begin{tabular}{|c|c|c|c|c|c|c|c|c|}
\hline \multicolumn{9}{|c|}{ Total respondents: 468} \\
\hline Gender: & \multicolumn{2}{|c|}{ Male } & \multicolumn{2}{|c|}{187} & \multicolumn{2}{|c|}{ Female } & \multicolumn{2}{|c|}{279} \\
\hline $\begin{array}{c}\text { Academic } \\
\text { year: }\end{array}$ & 1st & 155 & $2 n d$ & 147 & $3 r d$ & 139 & Honours & 24 \\
\hline $\begin{array}{c}\text { Repeating } \\
\text { any } \\
\text { subjects: }\end{array}$ & \multicolumn{2}{|c|}{ No } & \multicolumn{2}{|c|}{401} & \multicolumn{2}{|c|}{ Yes } & \multicolumn{2}{|c|}{61} \\
\hline
\end{tabular}

Source: Author's analysis

\subsection{Open-ended and closed-ended questions}

The results of the factors that promoted or prevented success are discussed in this section. This information was derived from the second section's open-ended questions in the questionnaire that asked students to list the factors that promoted or prevented their own success as well as the factors that promoted or prevented the other Thuthuka students' success. The reason why students were asked why they thought their fellow Thuthuka students were successful or not is that students may be more honest if they do not have to expose themselves, but can comment on their fellow students. These results are discussed together with the results of the other questions in section two of the questionnaire, which provide more detail on the factors influencing success.

\subsubsection{Factors promoting success}

The factors that were seen as promoting students' own success are set out in TABLE 2. These factors are defined in sections a) to e).

TABLE 2: Factors promoting students' own success

\begin{tabular}{lccc}
\hline & Number & \% (ofrespondents) & Ranking \\
\hline Support & 317 & 68 & 1 \\
Individual commitment & 306 & 65 & 2 \\
Motivation & 120 & 26 & 3 \\
Class attendance & 91 & 19 & 4 \\
Time management & 53 & 11 & 5 \\
Other & 16 & 3 & 6 \\
\hline
\end{tabular}

Source: Author's analysis 
According to the respondents, factors promoting other Thuthuka students' success were ranked exactly the same as those presented in TABLE 2. Support and individual commitment remained the two main factors promoting success. There was only one difference in the perceptions between male and female students and that was that male students ranked individual commitment above support as a success factor (refer to TABLE 3 ). The reason for the different perceptions of male and female students could not be determined from the questionnaire and could be a topic for future study.

TABLE 3: Factors promoting own success split between genders

\begin{tabular}{lcccc}
\hline & \multicolumn{2}{c}{ Male } & \multicolumn{2}{c}{ Female } \\
& Number & Ranking & Number & Ranking \\
\hline Support & 103 & 2 & 213 & 1 \\
Individual commitment & 130 & 1 & 175 & 2 \\
Motivation & 55 & 3 & 65 & 3 \\
Class attendance & 38 & 4 & 53 & 4 \\
Time management & 24 & 5 & 29 & 5 \\
Other & 9 & 6 & 7 & 6 \\
\hline
\end{tabular}

Source: Author's analysis

The most obvious difference in TABLE 4 (which shows the perceptions split between the different academic years) was that the first-year and the second-year students regarded support as the number one success factor and individual commitment as number two (same as the responses of the total group), whereas the third-year and honours students perceived individual commitment as being more important than support.

TABLE 4: Factors promoting own success split between academic years

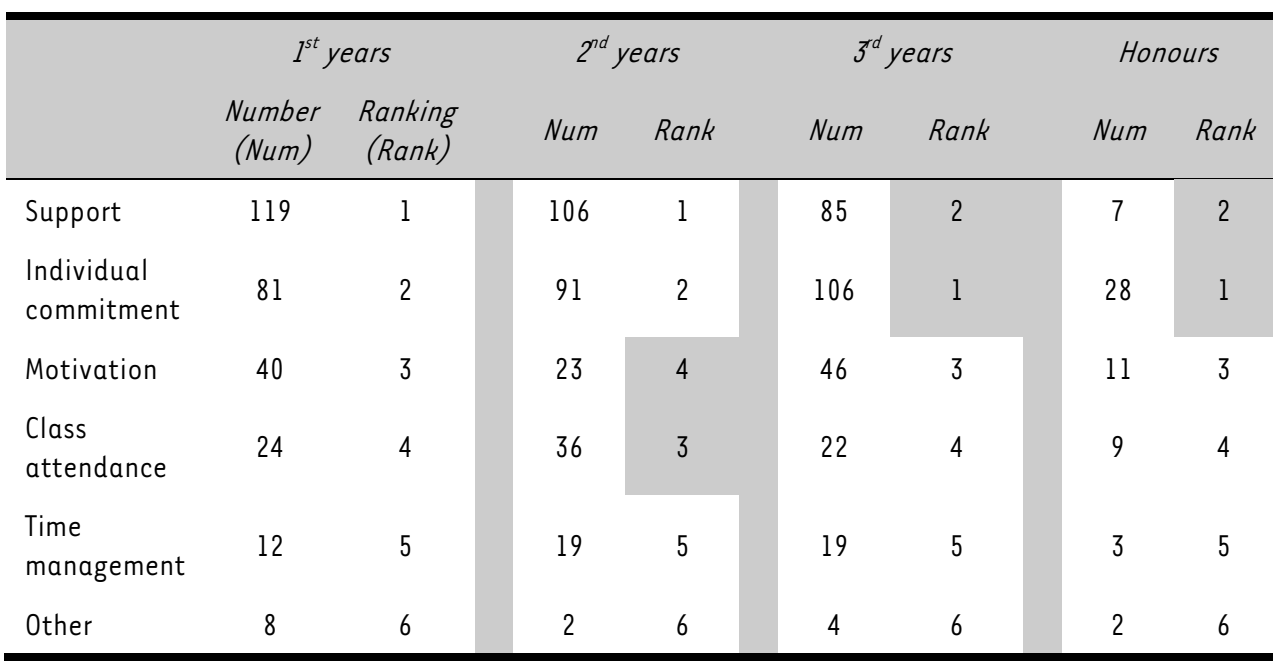

Source: Author's analysis 
The reasons for this could include (a) that the work is more difficult in the latter years of study, thus third-year and honours students have to work harder and are more aware of the importance of their own effort and (b) that support is initially more important (when students are adjusting to university life), but later they have benefited from the support, and have the skills, and now need to apply these skills by working on their own. The other difference between the academic years was that the second-year students perceived class attendance as being more important than motivation, as opposed to the other way around.

The perceptions of students who passed all their subjects at the first attempt were in line with the response of the group as a whole, but the students who had failed some of their subjects regarded individual commitment as being more important than support (refer to TABLE 5). It could be that the students who had failed some of their subjects now realised the importance of their own effort and that they should not rely on external support to such an extent.

TABLE 5: Factors promoting own success split between repeaters and non-repeaters

\begin{tabular}{lccccc}
\hline & \multicolumn{2}{c}{ Non-repeaters } & \multicolumn{2}{c}{ Repeaters } \\
& Number & Ranking & Number & Ranking \\
\hline Support & 279 & 1 & 36 & 2 \\
Individual commitment & 255 & 2 & 46 & 1 \\
Motivation & 101 & 3 & 16 & 3 \\
Class attendance & 76 & 4 & 11 & 4 \\
Time management & 45 & 5 & 8 & 5 \\
Other & 15 & 6 & 1 & 6 \\
\hline
\end{tabular}

Source: Author's analysis

a) Support

According to the students' perceptions, the main factor that contributed to their success was support, both academic and personal. Many students mentioned additional sources of help, such as attending tutorial classes, consulting lecturers for academic support, personal support by family or friends, studying in groups and making use of mentors (including student mentors, lecturer mentors and the Thuthuka coordinator). This evidence concurs with findings from previous studies, and highlights the importance of academic and personal support (Kleeman, 1994; Gerdes \& Mallinckrodt, 1994). A study by Crosling, Heagney and Thomas (2009) found that race also plays a role, as black students needed and used the services of support more often that non-black students. The following student responses (to the questionnaire employed in this study) show the perceived importance of support in achieving academic success:

- Thuthuka tutorials helped me a lot.

- The support system from my coordinators also contributed to my success.

- Thuthuka students are awarded mentors and it helps at boosting one's marks.

- Personal advice from the life coach and mentor, and support from fellow students

- Consulting with my lecturers and group discussions 
Students were asked where they would seek both academic and personal support and why. They mainly preferred to gain academic support by asking fellow Thuthuka students $(n=329)$, consulting the lecturer $(n=276)$ and asking classmates $(n=269)$. Students also indicated that they made use of mentors $(n=168)$ and attended support classes such as tutorials $(n=216)$. The main reason for choosing the specific support structure was that the person or persons they relied on were knowledgeable.

There were two main selections for the question 'Where do you seek personal support?' These were parents or family $(n=356)$ and friends (not class mates) $(n=311)$. Various other selections included fellow Thuthuka students $(n=149)$, class mates $(n=87)$, a mentor $(n=88)$ and other $(n=53)$. The main reasons for choosing the specific support structure was that the person they relied on knew the student $(n=224)$ and/or that the student trusted the person $(n=106)$.

The results and literature indicate that the students perceived academic and personal support to be of great importance in achieving success. This result would be satisfying to SAICA given the fact that a substantial number of support structures are offered to the Thuthuka students.

\section{b) Individual commitment}

Individual commitment included the factors hard work $(n=229)$, preparation $(n=33)$ and selfdiscipline $(n=44)$. This evidence is supported by Steenkamp et al. (2009), who found that hard work and practising the work are the two main factors promoting success. Some of the responses that indicated individual commitment as a significant factor in achieving success were the following:

- Prepare ahead of time.

- Constant hard work and studying most of the time

- Staying up to date

- Discipline, commitment and focus

Based on the results, it appears that the students were aware of the effort and commitment that are required to achieve success.

\section{c) Motivation}

Students regarded motivation as a factor that influences academic success. It is not only selfmotivation (internal) that they saw as being important, but also motivation from family and friends and from the Thuthuka initiative (external). Various other studies found that heightened motivation improves learning outcomes (Sadler \& Erasmus, 2005; Wells, De Lange \& Fieger, 2008). According to the students' comments, the factors perseverance and a passion for the course played a vital role in motivation.

Students were asked if they felt that the Thuthuka bursary drove them to success and in what way. The majority of the responses $(n=439)$ indicated that the bursary did indeed drive them to succeed in their course, while a mere 14 responses indicated otherwise and 15 students did not answer the question. The three main reasons why the bursary drove them were the academic and personal support $(n=209)$, that to be part of the Thuthuka programme was motivating $(n=166)$ and that students were afraid to lose their financial support $(n=101)$. These findings are in line with the main success factors indicated by the Thuthuka students discussed in 5.2.1.1 ('Support'). 
In order to determine whether interest in the course motivated the students, they were asked, 'If you had to make a choice now, would you have studied BCom Accounting (or equivalent) and why?' Of the respondents, 395 students answered 'yes' to this question, while 45 students answered 'no' and 28 students did not answer the question. The main reason the students gave for studying this course was that they had a passion for the course and enjoyed it $(n=213)$; the second reason was that they love a challenge $(n=94)$ and the last was that the course offers many opportunities $(n=71)$. The main reason why students did not want to study this course was that it is difficult $(n=115)$.

\section{d) Class attendance}

Various studies have found class attendance to be one of the factors influencing academic success (Steenkamp et al., 2008; Fraser \& Killen, 2005; Steenkamp, Baard \& Frick, 2012). The students were asked what percentage of their lectures they attended and the 468 respondents' average attendance rate was $94 \%$. From this result it can be concluded that the majority of the respondents regarded class attendance as an important factor for academic success.

\section{e) Time management}

In response to the question related to factors promoting success, only a small number of respondents ( $n=53)$ ascribed their academic success to good time management. However, when students were asked which factors prevented them from achieving success, they indicated that the main factor was bad time management. Joubert (2010) found that motivation and time management are linked, as students who are motivated will manage their time so that they have enough time for studying.

\subsubsection{Factors preventing success}

Students were asked which factors prevented their own success as well as the success of other Thuthuka students. The factors that were seen as preventing their own success are set out in TABLE 6. These factors are defined in a) to d)

TABLE 6: Factors hindering own success

\begin{tabular}{lccc}
\hline & Number & \% (of respondents) & Ranking \\
\hline Lack of time management & 207 & 44 & 1 \\
Too little individual commitment & 144 & 31 & 2 \\
Personal and academic problems & 109 & 23 & 3 \\
Not motivated & 52 & 11 & 4 \\
Other & 23 & 4 & 5 \\
\hline
\end{tabular}

\section{Source: Author's analysis}

According to the respondents, factors hindering other Thuthuka students' success were ranked exactly the same as in TABLE 6, except that time management and too little individual commitment were swapped around. Too little individual commitment $(n=221)$ and time management $(n=124)$ remained the two main factors hindering success. It could be that they blamed a lack of time management for their own failure but had the perception that their peers did not work enough. 
There were only two differences in the perceptions between male and female students. The male students ranked the lack of individual commitment above time management as a hindering factor and the female students ranked personal problems above too little individual commitment (refer to TABLE 7). The reason for the different perceptions by gender could not be determined from the questionnaire and could be a topic for future study.

TABLE 7: Factors hindering own success split between genders

\begin{tabular}{lcccc}
\hline & Male & \multicolumn{2}{c}{ Female } \\
& Number & Ranking & Number & Ranking \\
\hline Lack of time management & 57 & 2 & 116 & 1 \\
Too little individual commitment & 70 & 1 & 72 & 3 \\
Personal and academic problems & 54 & 3 & 88 & 2 \\
Not motivated & 19 & 4 & 33 & 4 \\
Other & 12 & 5 & 12 & 5 \\
\hline
\end{tabular}

Source: Author's analysis

There was only one difference in the perceptions related to academic years and that was that the third-year students ranked personal problems above the lack of individual commitment as a hindering factor (refer to TABLE 8), but the difference in opinion is not significant, as the number of respondents are small. All the students mentioned the difficulty of the course as part of their academic problems that were hindering their success.

TABLE 8: Factors hindering own success split between academic years

\begin{tabular}{|c|c|c|c|c|c|c|c|c|}
\hline & \multicolumn{2}{|c|}{$I^{s t}$ years } & \multicolumn{2}{|c|}{$2^{\text {nd }}$ years } & \multicolumn{2}{|c|}{$3^{d d}$ years } & \multicolumn{2}{|c|}{ Honours } \\
\hline & $\begin{array}{l}\text { Number } \\
\text { (Num) }\end{array}$ & $\begin{array}{l}\text { Ranking } \\
\text { (Rank) }\end{array}$ & Num & Rank & Num & Rank & Num & Rank \\
\hline $\begin{array}{l}\text { Lack of time } \\
\text { management }\end{array}$ & 56 & 1 & 60 & 1 & 47 & 1 & 10 & 1 \\
\hline $\begin{array}{l}\text { Too little } \\
\text { individual } \\
\text { commitment }\end{array}$ & 51 & 2 & 49 & 2 & 35 & 3 & 9 & 2 \\
\hline $\begin{array}{l}\text { Personal and } \\
\text { academic } \\
\text { problems }\end{array}$ & 46 & 3 & 43 & 3 & 45 & 2 & 9 & 3 \\
\hline $\begin{array}{l}\text { Not } \\
\text { motivated }\end{array}$ & 16 & 4 & 16 & 4 & 17 & 4 & 3 & 4 \\
\hline Other & 9 & 5 & 5 & 5 & 7 & 5 & 3 & 5 \\
\hline
\end{tabular}

Source: Author's analysis

The students who were repeating some subjects differed from the non-repeaters in that they perceived personal and academic problems to be a greater problem than a lack of individual 
commitment (refer to TABLE 9). They mentioned examination and study techniques as their main academic problem.

TABLE 9: Factors hindering own success split between repeaters and non-repeaters

\begin{tabular}{lcccc}
\hline & Non-repeaters & \multicolumn{2}{c}{ Repeaters } \\
& Number & Ranking & Number & Ranking \\
\hline Lack of time management & 141 & 1 & 29 & 1 \\
Too little individual commitment & 124 & 2 & 18 & 3 \\
Personal and academic problems & 118 & 3 & 24 & 2 \\
Not motivated & 45 & 4 & 7 & 4 \\
Other & 22 & 5 & 1 & 5 \\
\hline
\end{tabular}

Source: Author's analysis

a) Lack of time management

Compared to the 207 respondents who cited bad time management as the main factor hindering their own success, only 124 respondents believed that other students had time management issues. This may indicate that students are more likely to blame their failure on factors that are not under their control. Heavy work load and underestimating the course was also categorised as a lack of time management as students who had poor time management would not know how to handle these issues. Joubert (2010) emphasises that time management may have a great impact on academic success, because if students do not plan ahead, they may not be able to cover all the work before a test or examination.

The findings in this study support previous findings regarding time management as a hampering factor (Byrne \& Flood, 2005; Steenkamp et al., 2009). The following responses were received in the current study:

- I was not able to manage my time.

- Not coping with the work overload

- Procrastination

- Keep their work until the last minute before tests.

b) Too little individual commitment

Only 144 respondents admitted that they themselves were not committed to their studies, whereas 221 respondents believed that their fellow-students were not. This may indicate that students do not want to criticise themselves or put themselves in a bad light.

Lack of individual commitment included the factors laziness $(n=72)$, too much socialising $(n=58)$, not using the support provided $(n=9)$ and not concentrating in class $(n=5)$. Joubert (2010) contends that students underestimate the commitment and effort that they have to put into their studies. Bogle (2008) found that students regard college or university as a time to socialise. 
The following responses show that too little individual commitment is a factor hindering students' success (and that students were aware that they were not working hard enough):

- Hectic social lives, not focusing a lot on what's important at the moment (which is our studies)

- Laziness, partying without stop

- Lack of self-study

- Not asking for help when you are struggling

c) Personal and academic problems

Personal and academic problems included factors such as stress, lack of concentration, study techniques, examination techniques and peer pressure. Many respondents mentioned that they experienced stress because of the heavy work load and the difficulty of the course. They also mentioned that too much was being expected of Thuthuka students and that competition among students put pressure on them. This concurs with Bennett's (2003) findings concerning personal problems and Friedman and Mandel's (2009) findings that there is great competition among peers with respect to academic goals.

\section{d) Not motivated}

Some students $(n=52)$ regarded a lack of motivation as a reason for their failure. Many respondents mentioned that they did not have enough confidence. They also commented that students are demotivated when they fail a test. Regarding this issue, Mouton and Blake (1984, cited in Green \& Kelso, 2006) state that students will not perform effectively unless they are motivated, and without motivation they will not find learning rewarding or satisfying.

\subsection{Ranking of the pre-established list of factors}

In the third section of the questionnaire students were asked to rank a pre-established list of factors that may influence their success on a scale of 1 to 4 , with $1=$ no effect and 4 = huge effect. These items were categorised into high-level factors, and the three factors rated the highest by the students as contributing to their success were (1) support, (2) individual commitment and (3) motivation. These results strengthen and support the answers of the openended questions regarding the factors that promote students' success.

The main factor, support, included the items academic and personal support, and the students regarded these two items as being equally important. Individual commitment was made up of hard work, preparation and self-discipline, and students rated these three items jointly as the second most important factors for their success. The difference in the ratings of these three items was insignificant. The third most important factor was motivation, which included the motivation received from the Thuthuka bursary and self-motivation.

The factor that was rated the lowest and was perceived to have the least influence on their success was knowledge of school mathematics and accounting. This concurs with the findings related to the open-ended questions, as none of the students mentioned that their previous knowledge of mathematics and accounting was a factor that contributed to their success. This is in contrast with various studies that found that prior accounting and mathematics knowledge is an important factor for students to perform better (Mitchell, 1988; Tho, 1994; Gist, Goedde \& Ward, 1996). However, these studies were statistical correlation studies, whereas this study is 
based on student perceptions. Therefore it is possible that even though knowledge of school mathematics and accounting was perceived to be not important, statistically it might actually be important. Thuthuka students might not be able to see this factor as promoting or hindering their success.

\subsection{Results compared to other studies}

Motivation, individual commitment and regular class attendance were identified as the most important factors that influenced success in other studies of accounting students (Fraser \& Killen, 2003; Du Plessis et al., 2007; Steenkamp et al., 2009). The studies of Sadler and Erasmus (2005) and Kraft (1991) on the success factors of black students specifically showed that individual commitment (including consistent effort and self-discipline) was the main factor contributing to their success. This study confirmed these findings, as all of these factors were also mentioned as success factors by the Thuthuka students.

Contrary to other studies of accounting students that found that support was not the main success factor (Fraser \& Killen, 2003; Du Plessis et al., 2007; Steenkamp et al., 2009; Sadler \& Erasmus, 2005; Kraft, 1991), this study highlighted the importance of support for Thuthuka students. It could be argued that the fact that the Thuthuka students are given support and made aware of the importance of support (including asking questions to the lecturer; participating in mentor groups, tutorial classes and fellowship) might increase its perceived importance.

\section{CONCLUSION AND RECOMMENDATIONS}

In recent years, various academic initiatives have been implemented in an attempt to increase the number of black chartered accountants (Weil \& Wegner, 1997). SAICA initiated black advancement programmes as early as 1980 , and the Thuthuka Project is one of the most significant projects to have been launched for this purpose.

This study found that the two main factors that promote academic success for Thuthuka students are support and individual commitment. These students are reliant on academic, personal and financial support. They regard hard work, preparation and self-discipline as determinant factors in their academic success. They also mentioned that motivation, regular class attendance and good time management promoted their success.

Bad time management and too little individual commitment were the two main factors that prevented the success of Thuthuka students. Students commented that they did not know how to manage their time and that they were not putting enough effort into their studies. Other factors that hampered their success were personal and academic problems and a lack of motivation.

The main success factor for Thuthuka students that was identified (support) could be expected, as various support structures were offered to Thuthuka students and they were encouraged to utilise all the support that is available to them. The implications of the extensive support structures are that Thuthuka students could develop other skills (for example, those contained in the competency framework of SAICA) by participating in the support programmes which will benefit them in the future so that they will be well-rounded chartered accountants. It is recommended that the findings from this study be shared with other black students, the relevant lecturers and SAICA. Other black students should also be made aware of the support structures 
that are available to them and to use them optimally to gain value and to achieve academic success.

It appears that the Thuthuka Bursary Fund has an indirect influence on the academic success of the Thuthuka students. More funds should be raised, for example by the Thuthuka Bursary Fund, to allow educationally disadvantaged students to study full-time, resulting in a higher pass rate and the transformation of the chartered accounting profession. Mulder (SAICA, 2012c) stated that SAICA decided to tackle the urgent lack of black candidates being trained as CAs: 'SAICA black chartered accountants are pouring through the Thuthuka pipeline in a widening stream.' SAICA should make it their mission to make black students aware of opportunities such as the Thuthuka Project.

\section{LIST OF REFERENCES}

Bennett, R. (2003). Determinants of undergraduate student drop out rates in a university business studies department. Journal of Further and Higher Education, 27(2), pp. 123-141.

Bogle, K.A. (2008). Hooking up: Sex, dating, and relationships on campus. New York: New York University Press.

Bowman, N.A. \& Seifert, T.A. (2011). Can college students accurately assess what affects their learning and development? Journal of College Student Development, 52(3), pp. 270-290.

Byrne, M. \& Flood, B. (2005). A study of accounting students' motives, expectations and preparedness for higher education. Journal of Further and Higher Education, 29(2), pp. 111-124.

Byrne, M., Flood, B. \& Willis, P. (2002). The relationship between learning approaches and learning outcomes: a study of Irish accounting students. Accounting Education, 11(1), pp: 27-42.

Carpenter, V., Friar, S. \& Lipe, M. (1993). Evidence on the performance of accounting students: race, gender, and expectations. Issues in Accounting Education, 8(2), pp. 1-17.

Crosling, G., Heagney, M. \& Thomas, L. (2009). Improving student retention in higher education. Improving teaching and learning. Australian Universities Review, 51(2), pp. 9-18.

De Jager, $\varepsilon$. (2010). Studente se belewenis van ' $n$ hulpgroep in 'n eerstejaarsmodule in Finansiële Rekeningkunde. Unpublished Master's thesis. Stellenbosch: University of Stellenbosch.

De Lange, P., Waldmann, \&. \& Wyatt, K. (1997). Personal characteristics and academic achievement of undergraduate accounting students studying through open learning. Accounting Education, 6(4), pp. 295-306.

Du Plessis, A., Muller, H. \& Prinsloo, P. (2007). Validating the profile of a successful first year accounting student. Meditari Accountancy Research, 15(1), pp. 19-33.

Fraser, W.J. \& Killen, R. (2003). Factors influencing academic success or failure of first-year and senior university students: do education students and lecturers perceive things differently? South African Journal of Education, 23(4), pp. 254-260.

Fraser, W.J. \& Killen, R. (2005). The perceptions of students and lecturers of some factors influencing academic performance at two South African universities. Perspectives in Education, 23(1), pp. 25-40. 
Friedman, B.A. \& Mandel, R.G. (2009). The prediction of college student academic performance and retention: Application of expectancy and goal setting theories. Journal of College Student Retention: Research, Theory and Practice, 11(2), pp. 227-246.

Gerdes, H. \& Mallinckrodt, B. (1994). Emotional, social and academic adjustment of college students: A longitudinal study of retention. Journal of Counselling and Development, 72, pp. 281-288.

Gist, W.E., Goedde, H. \& Ward, B.H. (1996). The influence of mathematical skills and other factors on minority student performance in principles of accounting. Issues in Accounting Education, 11(1), pp. 49-60.

Gracia, L. \& Jenkins, $\varepsilon$. (2002). An exploration of student failure on an undergraduate accounting programme of study. Accounting Education, 11(1), pp. 93-107.

Harrell, A., Caldwell, C. \& Doty, ع. (1985). Within-Person expectancy theory predications of accounting students' motivation to achieve academic success. The Accounting Review, 60 (4), pp. 724-735.

Isaacs, D. (2007)). Tutoriaalprogram vir openbare en ontwikkelingsbestuur-Bystand aan eerstejaars. [Online] Available: http://academic.sun.ac.za/sol/tmsu/KOL/2007feb/hoofart. (Accessed 21 February 2008).

Joubert, J.A. (2010). Significant predictors of success and non-completion in first year accounting at a South African University. Unpublished PhD thesis. Bloemfontein: University of the Free State.

Kleeman, G.L. (1994). Achieving academic success with ethnically diverse students: implications for student affairs. NASPA Journal, 31(2), pp. 137-149.

Kraft, C.L. (1991). What makes a successful black student on a predominantly white campus? American Educational Research Journal, 28(2), pp. 423-443.

Malele, I. (2011). Access to Higher Education: Challenges: Higher Education SA briefing. [Online] Available: http://www.pmg.org.za/report/20110208. (Accessed 9 June 2011).

McInnis, C. (2003). New realities of the student experience: how should universities respond? Proceedings of the Twenty-fifth Annual Conference of the European Association for Institutional Research, 24-27 August, Limerick, Ireland.

Memani, K. (1994). Development of black accountants in the changing SA. In $\varepsilon$. Sadler. (2003). Aspects of higher education and black chartered accountants: Empirical findings. South African Journal of Higher Education, 17(1), pp. 156-165.

Mitchell, F. (1988). High school accounting and student performance in the first level university accounting course: A UK study. Journal of Accounting Education, 6, pp. 279-291.

Monroe, S.A. (2002). Effecting self-efficacy in intermediate elementary students doing mathematical problem solving. Proceedings of the Linking Research to Education Conference, 15-17 July, University of Calgary.

Mouton, J.S. \& Blake, R.R. (1984). Synergogy: A New Strategy for Education, Training and Development. In T.M. Green \& C.M. Kelso. (2006). Factors that affect motivation among adult learners. Journal of College Teaching \& Learning, 3(4), pp. 65-74.

Naudé, દ. (2002). Sooo... you're a lecturer! [Online] Available: http://www.sacla.org.za/SACLA2002/Proceedings/Papers/Naude.pdf. (Accessed_3 September 2009). 
Odendaal, E.M. \& Joubert, K. (2011). Alleviating the critical accounting skills shortage in South Africa: a distance learning perspective. Southern African Journal of Accountability and Auditing Research, 11, pp. 23-34.

Ozga, J. \& Sukhnandan, L. (1998). Undergraduate Non-completion: Developing an Explanatory Model. Higher Education Quarterly, 52(3), pp. 316-333.

Pritchard, M.E. \& Wilson, G.S. (2003). Using emotional and social and social factors to predict student success. Journal of College Student Development, 44(1), pp. 18-28.

Rudman, R. (2011). Accounting profession addressing one of Africa's biggest problems: Education. Accountancy SA.

Sadler, $\varepsilon$. (2003). Aspects of higher education and black chartered accountants: Empirical findings. South African Journal of Higher Education, 17(1), pp. 156-165.

Sadler, E. \& Erasmus, B.J. (2003). Views of black trainee accountants in South Africa on matters related to a career as a chartered accountant. Meditari Accountancy Research, 11, pp. 129-149.

Sadler, E. \& Erasmus, B.J. (2005). The academic success and failure of black chartered accounting graduates in South Africa: A distance education perspective. Meditari Accountancy Research, 13(1), pp. 29-50.

SAICA. South African Institute of Chartered Accountants. (2009). New data revea/ a dramatic increase in black chartered accountants. [Online] Available:

https://www.saica.co.za/Home/tabid/36/itemid/1448/language/en-US/Default.aspx. (Accessed 9 June 2011).

SAICA. South African Institute of Chartered Accountants. (2011a). About - Transformation and Growth. [Online] Available:

https://www.saica.co.za/About/TransformationandGrowth/tabid/712/language/enZA/Default.aspx. (Accessed 9 June 2011).

SAICA. South African Institute of Chartered Accountants. (2011b). Membership statistics. [Online] Available: https://www.saica.co.za/Portals/0/Members/race2011.pdf. (Accessed 2 March 2012).

SAICA. South African Institute of Chartered Accountants. (2011c). Address by Minister of Higher Education and Training Dr Blade Nzimande at the Thuthuka Donor Appreciation Evening. [Online] Available:

https://www.saica.co.za/News/NewsArticlesandPressmediareleases/2010/tabid/2313/itemid/2281/ language/en-ZA/language/en-ZA/Default.aspx. (Accessed 17 February 2012).

SAICA. South African Institute of Chartered Accountants. (2011d). Successful Black PEI Repeat Candidates Honoured. [Online] Available:

https://www.saica.co.za/News/NewsArticlesandPressmediareleases/tabid/695/itemid/3151/langua ge/en-ZA/language/en-ZA/Default.aspx. (Accessed 17 February 2012).

SAICA. South African Institute of Chartered Accountants. (2012a). Thuthuka campaign. [Online] Available: https://www.saica.co.za/LearnersStudents/Thuthuka/tabid/714/language/enZA/Default.aspx. (Accessed 16 January 2012).

SAICA. South African Institute of Chartered Accountants. (2012b). Thuthuka Bursary Fund. [Online] Available:

https://www.saica.co.za/LearnersStudents/Thuthuka/ThuthukaBursaryFund/tabid/716/language/e n-ZA/Default.aspx. (Accessed 13 February 2012). 
SAICA. South African Institute of Chartered Accountants. (2012c). SAICA drives transformation in Accountancy. [Online] Available:

https://www.saica.co.za/News/NewsArticlesandPressmediareleases/tabid/695/itemid/3348/langua ge/en-US/Default.aspx. (Accessed 9 March 2012).

Schmelzer, R.V., Schmelzer, C.D., Figler, R.A. \& Brozo, W.G. (1987). Using the critical incident technique to determine reasons for success and failure of university students. In W.J. Fraser \& R. Killen. (2005). The perceptions of students and lecturers of some factors influencing academic performance at two South African universities. Perspectives in Education, 23(1), pp. 25-40.

Sehoole, I. (2010). Renewed assurance for SA's future pipeline of world-class chartered accountants. [Online] Available:

https://www.saica.co.za/News/NewsArticlesandPressmediareleases/2006/tabid/704/itemid/188/la nguage/en-ZA/language/en-ZA/Default.aspx. (Accessed 5 March 2012).

Selebi, N. (2007). Thuthuka Development Programme. [Online] Available: http://www.skillsforbiodiversity.org.za/strategies/biodiversity-sector-hcd-strategy1/biodiversity-sector-human-capital-development-strategy/Thuthuka-development-programme$1 \# 350,1$, Thuthuka ${ }^{\circledR}$ Development Programme. (Accessed 9 June 2011).

SMVPS. SAICA Motor Vehicle Purchasing Scheme. (2012). Thuthuka - A successful model for transforming the chartered accountancy profession. [Online] Available: http://www.smvps.co.za/files/Thuthuka.pdf. (Accessed 16 January 2012).

Steenkamp, L.P., Baard, R.S. \& Frick, B.L. (2009). Factors influencing success in first-year accounting at a South African university: A comparison between lecturers' assumptions and students' perceptions. South African Journal of Accounting Research, 23(1), pp. 113-140.

Steenkamp, L.P., Baard, R.S. \& Frick, B.L. (2012). A holistic investigation into a tutor programme in first-year Financial Accounting. Meditari Accountancy Research, 20(1), pp. 68-87.

Stephen, D.F., Welman, J.C. and Jordaan, W.J. (2004). English language proficiency as an indicator of academic performance at a tertiary institution. SA Journal of Human Resource Management, 2(3), pp. $42-53$.

Tho, L.M. (1994). Some evidence on the determinants of student performance in the University of Malaya introductory accounting course. Accounting Education, 3(4), pp. 331-340.

Weil, S. \& Wegner, T. (1997). Increasing the number of black chartered accountants in South Africa: an empirical review of educational issues. Accounting education, 6(4), pp. 307-323.

Wells, P., De Lange, P. \& Fieger, P. (2008). Integrating a virtual learning environment into a secondyear accounting course: determinants of overall student perception. Accounting and Finance, 48, pp. 503-518.

Wong, D.S.N. \& Chia, Y. (1996). English language, mathematics and first year financial accounting performance: a research note. Accounting Education. 5(2), pp. 183-189. 